\title{
Interview Prof. Gerard George, Imperial College London
}

\section{Interview Question}

Open innovation for the greater good gains momentum in the health care industry. What are the challenges for management research in this regard? What are the most important questions you recommend researchers should study in the future?

\section{Author: Prof. Gerard George, Imperial College London}

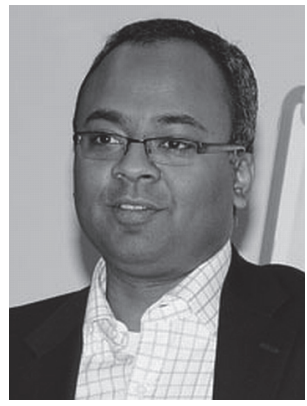

With the cost of health care increasing exponentially, new business models for organizing and commercializing innovation are critical, not just in less developed countries, but acutely so in developed economies. Three related issues merit scholarly inquiry: (1) collaboration benefits and coordination costs, (2) incentives and ownership, and (3) partnerships and governance. Every firm has to be 'organized' effectively to allow inventors from different technical fields to come together to innovate. Some of my prior work in biotechnology suggests that inventions have higher impact when the inventors come from moderately distant scientific domains, ${ }^{1}$ but this distance creates lack of mutual knowledge and incurs costs to coordinate across teams. ${ }^{2}$ Here, examining the benefits of collaboration (who gets what?) versus the costs of coordination (how difficult is it?) in organizational design is likely to be a predictor of success. Relatedly, the ownership of intellectual property assets and the incentives to collaborate will determine if there is enough interest behind a particular initiative. Incentives need not be only economic in nature. Grand challenges or 'prizes' are popular avenues to attract attention on solving healthcare problems, but the success of these efforts have not been documented systematically. ${ }^{3}$ How do incentives, whether extrinsic (such as money) or intrinsic (such as aspiration and goodwill), influence whether new business models are successful is a central issue. Thirdly, the formation of public-private partnerships or multi-party partnerships increase both coordination costs and incentive problems, but are more likely to create breakthrough successes by sharing complementary resources. ${ }^{4}$ These factors together will help shape how, when, and under what conditions 'openness' will be fruitful to our collective future.

1 Kotha, R./Zheng, Y./George, G. (2011): Entry into new niches: The effects of firm age and the expansion of technological capabilities on innovative output and impact, in: Strategic Management Journal, Vol. 32, No. 9, pp. 1011-1024.

2 Kotha, R./George, G./Srikanth, K. (2012): Bridging the mutual knowledge gap: Coordination costs and the commercialization of science, in: Academy of Management Journal.

3 Dahlander, L./Gann, D./George, G. (2012): Taxonomy-Analytical Study for the Project on Open Collaborative Projects and IP-Based Models (Rec. 36), World Intellectual Property Organization, Geneva, Switzerland.

4 George, G./McGahan, A.M./Prabhu, J.C. (2012): Innovation for inclusive growth: Towards a theoretical framework and research agenda, in: Journal of Management Studies, Vol. 49, No. 4, pp. 661-683. 
Gerard George is Professor of Innovation and Entrepreneurship at the Imperial College Business School, London, and founding director of The Rajiv Gandhi Centre at Imperial College London, UK. 